INTRODUCTION TO THEORETICAL PHYSICS 
EXTRACTS FROM REVIEWS OF THE $3^{\text {rd }} A N D 4^{\text {th }}$ GERMAN EDITIONS OF PROFESSOR HAAS'S “EINFÜHRUNG IN DIE THEORETISCHE PHYSIK."

I. Zeitschrift Fír Physikalische Chemre:- ... In the reviewer's opinion, it is just to the readers of this journal, who desire to make a serious study of physics, that Haas's book can be most emphatically recommended. The reader, however, should not merely read, but work through it ; for it is the only book which carries the learner so far into theoretical physics as to enable him to master its scientific principles and methods, with a view to the study of more advanced special works. . . .

2. ZetTsCheift Fir INSTRUMENTENKUNDE:- ... The ground covered by the autbor is so excellently treated, botb in logical construction and in methods of proof, that the work is undoubtedly to be considered as one of the best of its kind. ...

3. Die Naturwissenschaften:- ... This excellent and most readable book deserves the widest circulation. . . .

4. Physikalische Zeitschrift:- ... The exposition is as elegant as it is intelligible, and the work is distin. guished by its great lucidity. ...

5. Prarmazeutische Monatshepte:- ... This work nceds no recommendation, for it is a masterpiece of the scientific art of exposition. . . . 


\title{
INTRODUCTION TO THEORETICAL PHYSICS
}

VOLUME I

\author{
BY \\ ARTHUR HAAS, Pн.D. \\ PROFESSOR OF PHYSICS IN THE UNIVERSITY OF VIENMA \\ TRANSLATED FROM THE THIRD AND FOURTH \\ EDITIONS BY \\ T. VERSCHOYLE, M.C., B.Sc., A.R.C.S. \\ WITH A FOREWORD BY \\ PROF. F. G. DONNAN, F.R.S.
}

\author{
LONDON \\ CONSTABLE \& COMPANY LTD \\ IO-I 2 ORANGE STREET W.C. 2 \\ BOMBAY AND SYDNEY \\ 1924
}


Printed in Great Britain by The Whitefriars Press, Ltd., London and Tonbridge. 